International Journal of

Supply Chain and Logistics

(IJSCL)

RELATIONSHIP BETWEEN HEDGING RISK MANAGEMENT STRATEGY AND SUPPLY CHAIN PERFORMANCE AMONG MANUFACTURING COMPANIES IN KENYA

DR. MBURU DAVID KIARIE, DR. PATRICK K. NGUGI AND DR. KENNEDY O. OGOLLAH

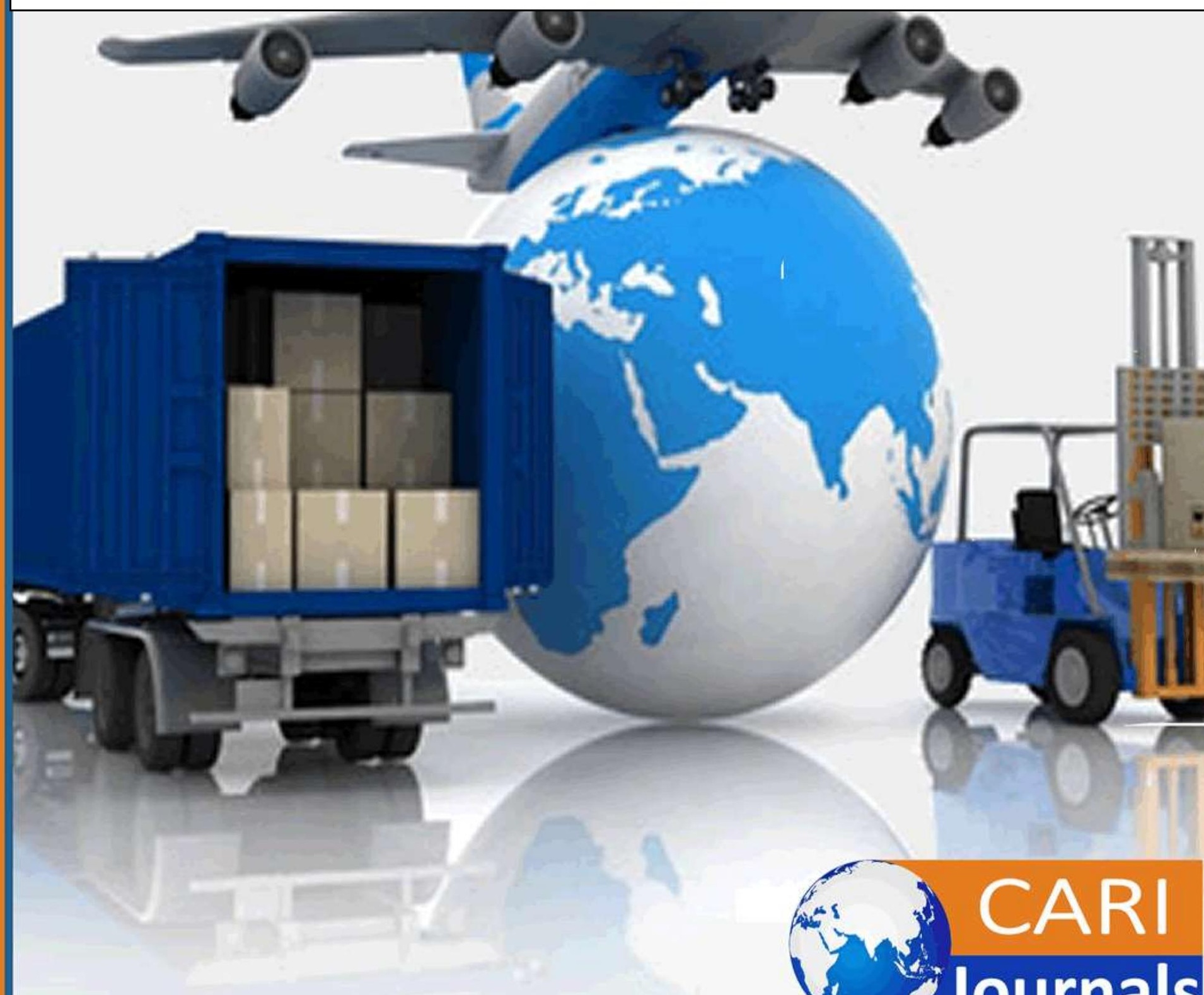




\title{
RELATIONSHIP BETWEEN HEDGING RISK MANAGEMENT STRATEGY AND SUPPLY CHAIN PERFORMANCE AMONG MANUFACTURING COMPANIES IN KENYA
}

\author{
1*Dr.Mburu David Kiarie \\ Doctorate student, Jomo Kenyatta University of Agriculture and Technology, Kenya \\ Corresponding email address: dmburu77@gmail.com \\ ${ }^{2}$ Dr. Patrick K. Ngugi \\ Lecturer, Jomo Kenyatta University of Agriculture and Technology, Kenya \\ ${ }^{3}$ Dr. Kennedy O. Ogollah \\ Lecturer, University of Nairobi, Kenya
}

\begin{abstract}
Purpose: The purpose of this study was to determine therelationship between hedging risk management strategy and supply chain performance among manufacturing companies in Kenya

Methodology:The study adopted a cross-section survey of descriptive nature .The target population comprised of the 412 manufacturing companies within Nairobi County that were registered members of KAM. The fisher et al formula for calculating the sample size was used to yield a sample size of 199. Data was collected using questionnaires and analyzed using statistical package of social sciences (SPSS) version 21 as a tool of analysis.

Results: The study findings revealed that the companies that increased buffer stock at various levels in the supply chain. Increasing buffer stock at various levels in the supply chain resulted to decreased lead time, improved quality and reduced cost. Results also showed that most of the companies 'conducted reduce order cycle times. Conducting reduce order cycle times resulted to decreased lead time, improved quality and reduced cost. Further, the results revealed that most of the companies shared supply chain costs with partners. Sharing supply chain costs with partners resulted to decreased lead time, improved quality and reduced cost.

Policy recommendation:the study recommended that manufacturing companies should put in place a risk analysis and evaluation management strategy to enhance supply chain performance. In particular, companies should consider conducting whole life costing of suppliers and also internal quality of suppliers.
\end{abstract}

Keywords: Hedging risk management strategy, performance, manufacturing companies 
International Journal of Supply Chain and Logistics

ISSN $\quad$ Xxxx-Xxxx $\quad$ (Paper) ISSN

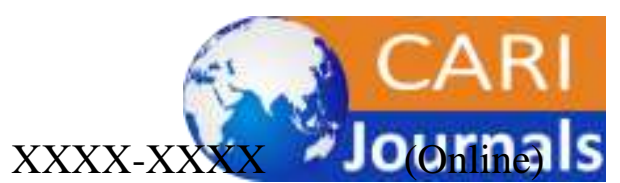

Vol.1, Issue No.2, pp82 - 100, 2017

www.carijournals.org

\subsection{Introduction}

Today's market place is characterized by turbulence and uncertainty. Market turbulence has tended to increase in recent years for several reasons the supply chain. Demand in almost every industry sector seems to be more volatile. Product and technology life-cycles have shortened significantly and competitive product introduction make life cycle demand difficult to predict (WB, 2012). Considerable 'chaos' exists in supply chains through the effect of such actions as sales promotion, quarterly sales incentives or decision rules such as quantities which results into continuous disruptions along the supply chain (Singhal\& Hendricks, 2005).

Today, vulnerability of Supply chains to disturbances or disruptions has increased and has received considerable attention by practitioners as well as academics (Skipper \& Hanna, 2009). It's not only the effect of external events such as natural disasters but also the impacts of changes in business strategy, the impact of one entity in the supply chain failing can as well lead to a number of entities closing down and in some instances the whole supply chain shuts down. The risk implications of the entwined global marketplace that characterize today's supply chains have also been evidenced vividly in the recent global financial crisis. Many companies have experienced a change in their supply chain risk profile as a result of changes in their supply chain profile and changes in their business models. The adoption of 'lean' practices, the move to outsourcing and a general tendency to reduce the size of the supplier base potentially increase supply chain vulnerability (Richard, 2008).

The level of decision making along supply chain in manufacturing companies, quality of service and the type of relationship with other organizations generally influences the level of outputs expected from the functional and tertiary groups (Cooper \&Ellram, 2003). The diversity and complexity of organizations, growth, strategic conceptualization \& pursuit of adaptive mechanisms coupled with adverse changes in technology, and the global competitiveness of different markets, is beyond the efforts of an organization alone but between the supply chains (Cox \& Watson, 2001). Most literature reveal that supply chain performance in manufacturing companies is more appropriate as units of analysis than the entire organization management with the realization of the fact that those involved in the chain are in a position to lead in a number of possible directions (Miller \& Ross, 2003).

Today's marketplace is shifting from individual company performance to supply chain performance: the entire chain's ability to meet end-customer needs through product availability and responsive, on-time delivery (Chen \&Labadi, 2005). Supply chain performance crosses both functional lines and company boundaries. Functional groups (engineering/R\&D, manufacturing, and sales/marketing) are all instrumental in designing, building, and selling products most efficiently for the supply chain, and traditional company boundaries are changing as companies discover new ways of working together to achieve the ultimate supply chain goal: the ability to fill customer orders faster and more efficiently than the competition (Abdullah \& Abdel, 2004). The process of choosing appropriate supply chain performance measures is difficult due to the complexity of these systems in manufacturing companies. The performance of a supply chain in manufacturing companies is characterized by its ability to remain market-sensitive without losing the integration through the chain. One of the difficulties in designing and analyzing a supply chain in these companies is that its processes are 
International Journal of Supply Chain and Logistics

ISSN $\quad$ Xxxx-Xxxx $\quad$ (Paper) ISSN

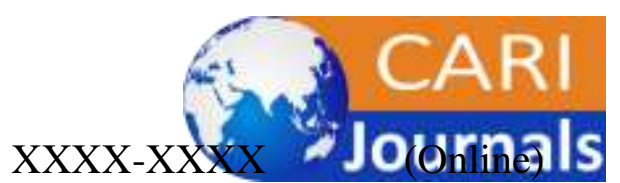

Vol.1, Issue No.2, pp82 - 100, 2017

www.carijournals.org

governedby the strategic attributes of the supply chain (Lysons, 2006). In today's world, supply chain management (SCM) is a key strategic factor for increasing organizational effectiveness and for better realization of organizational goals such as enhanced competitiveness, better customer care and increased profitability (Bosman, 2006).

The globalization of markets and outsourcing has made many manufacturing companies select supply chain and logistics to manage their operations. Most of these companies realize that, in order to evolve an efficient and effective supply chain, SCM needs to be assessed for its performance to reduce risk of disruptions (Van \&Beulens, 2002). Supply chain management (SCM) has been a major component of competitive strategy to enhance organizational productivity and profitability as well as metric measure, however performance pertaining to Supply chain and risks pertaining to disruptions among manufacturing companies has not received adequate attention from researchers or practitioners today (Wegner \& Bode, 2006).

\subsection{Statement of the Problem}

In the current global downturn, businesses are being hit by falling demand and unpredictable global supply costs which will expose these and other built in supply chain vulnerabilities. The key questions are, do business leaders understand these vulnerabilities and does their supply chain team have the capability to identify them and present the plans to mitigate them? In most cases the answer is no. In tough times businesses need to focus absolutely on profit, cash flow and eliminating unpredictable events from a declining demand profile (WB, 2012).Businesses processes today are endangered due to increased vulnerabilities as a result of risks along the process of enhancing performance in the organization (Suhong, Bhanu, Ragu \& Rao, 2006).

Several studies reveal that Supply chains collapses at an alarming rate due to continuous risk disruptions in developing nations in the world (Singhal\& Hendricks, 2005). Past studies showed that most supply chains fail within first three years of business operations (Bosman, 2006). According to World Bank report (2013), companies with poor supply chain performance experienced $33-40 \%$, lower stock of returns and approximately $70 \%$ to $80 \%$ of these companies' supply chains fail within 1-3 years (WB, 2013). It's also evident that share price volatility in the year after the supply chain performance drop goes to $13.5 \%$ higher compared with volatility in the year before the disruption (Hendricks \&Singhal, 2005).

Poor Supply chain performance reduces company's revenue, cut into market share, inflate company's cost, increase budget and threaten production up to $60 \%$, damage a company's credibility with investors and other stakeholders, thereby driving up its cost of capital; such firms experienced $7 \%$ lower sales, $11 \%$ higher costs and 14\% increase in inventories (Ruud \&Bosman, 2006).

According to a study by Sean and Kilcarr, (2013) on Third-Party Logistics, economic losses due to poor supply chain performance among manufacturing companies increased by $465 \%$ over the last three years climbing from \$62 billion in 2009 to well over $\$ 350$ billion in 2011 .

A study by the Public Procurement Authority (PPOA) (2013) revealed that most of the tendered products/services are being brought with a mark-up of $60 \%$ on the market price hindering the supply chain performance due to high costs (Kirungu, 2012). This means that supply chains performance in Kenya is at a high risk of inadequate risk interference and influence. Further Howarth and Fredericks (2012) identifies that Small and Medium Enterprises (SMEs) 
International Journal of Supply Chain and Logistics

ISSN $\quad$ XXxx-Xxxx $\quad$ (Paper) ISSN

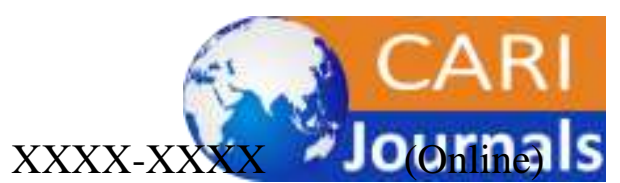

Vol.1, Issue No.2, pp82 - 100, 2017

www.carijournals.org

manufacturers contributed to 70\% of the Kenyan Gross Domestic Product (GDP) in 2011 whose operations are entirely depended on the performance of their supply chains, however increased non-performance of their supply chains due to risk interference, have resulted to a major stagnation in their profit margin reducing the GDP at an alarming rate. Statistics from Economic Survey (2014) show that Supply chain performance in manufacturing companies is a component of Kenya's overall GDP. In the last 31 years, it has been greatly fluctuating. In 1980, industry and manufacturing accounted for 21 percent of Kenya's overall GDP. In 1990, it decreased to 19 percent, and in 2000, the value added to GDP decreased again to $17 \%$. In 2011, there was a slight rise to $19 \%$ of Kenya's overall GDP (WB, 2013). This sudden change in GDP calls for immediate solution to the manufacturing companies' supply chains risk disruptions since Kenya's economy is market-based, and maintains a liberalized external trade system, hence the need for this study.

\subsection{LITERATURE REVIEW}

\subsection{Theoretical review}

\subsubsection{Enterprise Risk Management Model}

The Enterprise Risk Management (ERM) Model is a system used to analyze the cost and benefit of addressing risks. This system measures risk using a combination of qualitative and quantitative methods to set a standard method for analyzing risk across the many functions within the different departments in an organization. Risks generally fall within five categories regardless of the subject matter of the subsystem. These categories are (1) risks to people, (2) risks that hinder mission accomplishment, (3) risks to departmental physical assets, (4) financial risks, and (5) risks that destroy credibility and trust by the customers, stakeholders, and the general public (Cooper, 2003).

A comparison of rough costs estimates for potential risks and the controls that address them can help the Department ensure that all risks are sufficiently addressed through acceptance, monitoring, mitigation and avoidance. This system also ensures that controls are not applied when the cost of the controls exceeds the cost of risk acceptance (Sheffi, 2005).

Further the preliminary review of each subsystem begins with a risk analysis performed by a team of senior level representatives of a department in an organization. This team performs the risk analysis using five steps. First Identifying Risks which List all possible events that could occur in a subsystem if there are no controls. Once risks are identified, combine like risks according to the following key areas impacted by the risks, people, mission, physical assets, financial assets, and customer/stakeholder trust. Secondly, Evaluating Risks involves rating risks according to probability and impact (Brown, 2001). Also Identify Existing Risk Mitigation which includes listing all controls that would exist without subsystem-specific controls. Further Identify New Risk Controls Where there is a significant or extreme risk rating, list gaps between existing risks and existing controls. For risks rated moderate, proposed controls must demonstrate a clear benefit (approval of a mission need) level cost-benefit analysis. Lastly, Risk Register is a step that creates a register that documents the results of the risk evaluation, including the events, probabilities, impacts, and risk management strategy (Reck, 2005). This theory explicitly explains the application and relevance of the risk analysis and evaluation management strategy in this research. 
International Journal of Supply Chain and Logistics

ISSN

XXXX-XXXX

(Paper)

ISSN

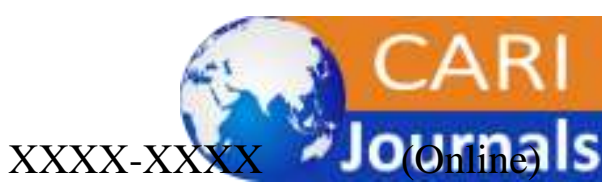

Vol.1, Issue No.2, pp82 - 100, 2017

www.carijournals.org

\subsection{METHODOLOGY}

The study adopted a cross-section survey of descriptive nature. The target population comprised of the 412 manufacturing companies within Nairobi County that were registered members of KAM. The fisher et al formula for calculating the sample size was used to yield a sample size of 199. Data was collected using questionnaires and analyzed using statistical package of social sciences (SPSS) version 21 as a tool of analysis.

\subsection{RESULTS FINDINGS}

\subsection{Hedging Against Risk Management Strategy}

\subsubsection{Buffer Stock}

The respondents were asked whether their company increase buffer stock at various levels in the supply chain. Result in Figure1 show that a majority of the respondents $(80 \%)$ indicated that their company increase buffer stock at various levels in the supply chain.

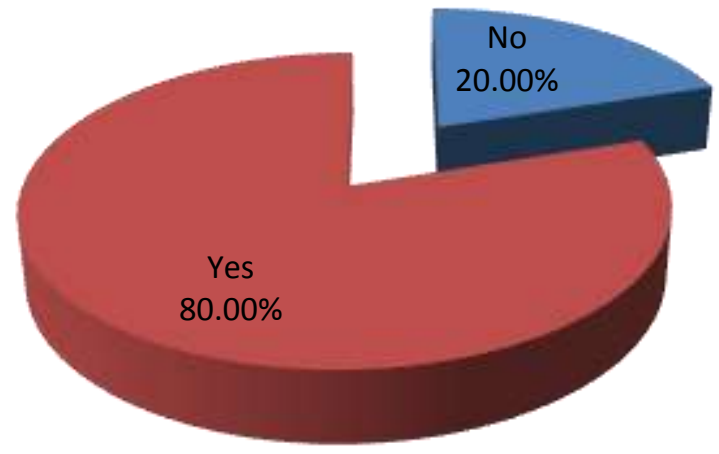

\section{Figure 1: Buffer Stock}

Results in Table 1 show that majority of the respondents (53.1\%) indicated that increased buffer stock at various levels in the supply chain has decreased lead time by more than $10 \%$ while $46.9 \%$ of the respondents indicated that increased buffer stock at various levels in the supply chain has decreased lead time by a range of $6-10 \%$. Results in Table 1 also shows that majority of the respondents $(58.3 \%)$ indicated that increased buffer stock at various levels in the supply chain has improved quality by more than $10 \%$ while $41.7 \%$ of the respondents indicated that increased buffer stock at various levels in the supply chain has improved quality by a range of 6-10\%. Further, results in Table 4.40 also shows that majority of the respondents $(54.2 \%)$ indicated that increased buffer stock at various levels in the supply chain has reduced cost by more than $10 \%$ while $45.8 \%$ of the respondents indicated that increased buffer stock at various levels in the supply chain has reduced cost by a range of 6-10\%. 
International Journal of Supply Chain and Logistics

ISSN

XXXX-XXXX

(Paper)

ISSN

Vol.1, Issue No.2, pp82 - 100, 2017

www.carijournals.org

Table 1: Buffer Stock (YES)

\begin{tabular}{|c|c|c|}
\hline Statement & Indicator & Percentage \\
\hline \multirow[t]{5}{*}{ Buffer stock and lead time supply chain performance } & $\begin{array}{l}\text { Decreased lead } \\
\text { time by } 0-5 \%\end{array}$ & $0.00 \%$ \\
\hline & $\begin{array}{l}\text { Decreased lead } \\
\text { time by } 6-10 \%\end{array}$ & $53.10 \%$ \\
\hline & $\begin{array}{l}\text { Decreased lead } \\
\text { time by more than }\end{array}$ & \\
\hline & $10 \%$ & $46.90 \%$ \\
\hline & Total & $100.00 \%$ \\
\hline \multirow[t]{6}{*}{ Buffer stock and quality of supply chain performance } & $\begin{array}{l}\text { Improved quality } \\
\text { by } 0-5 \%\end{array}$ & $0.00 \%$ \\
\hline & Improved quality & \\
\hline & by $6-10 \%$ & $41.70 \%$ \\
\hline & $\begin{array}{l}\text { Improved quality } \\
\text { by more than } 10 \%\end{array}$ & $58.30 \%$ \\
\hline & Total & $100.00 \%$ \\
\hline & Reduced cost by & \\
\hline \multirow[t]{5}{*}{ Buffer stock and cost of supply chain performance } & $0-5 \%$ & $0.00 \%$ \\
\hline & Reduced cost 6- & \\
\hline & $10 \%$ & $45.80 \%$ \\
\hline & $\begin{array}{l}\text { Reduced cost by } \\
\text { more than } 10 \%\end{array}$ & $54.20 \%$ \\
\hline & Total & $100.00 \%$ \\
\hline
\end{tabular}

Results in Table 2 show that a majority of the respondents (58.3\%) indicated that increased buffer stock at various levels in the supply chain has increased lead time by a range of 6-10\% while $41.7 \%$ of the respondents indicated that increased buffer stock at various levels in the supply chain has increased lead time by more than $10 \%$. Results in Table 2 also shows that $50 \%$ of the respondents indicated that increased buffer stock at various levels in the supply chain has decreased quality by a range of $6-10 \%$ while $50 \%$ of the respondents indicated that increased buffer stock at various levels in the supply chain has decreased quality by more than $10 \%$. Further, results in Table 2 also shows that majority of the respondents (54.2\%) indicated that increased buffer stock at various levels in the supply chainhas increased cost by more than $10 \%$ while $45.8 \%$ of the respondents indicated that increased buffer stock at various levels in the supply chain has increased cost by a range of 6-10\%. 
International Journal of Supply Chain and Logistics

ISSN

XXXX-XXXX

(Paper)

ISSN

Vol.1, Issue No.2, pp82 - 100, 2017

Table 3: Buffer Stock (NO)

\begin{tabular}{|c|c|c|}
\hline Statement & Indicator & $\begin{array}{l}\text { Percentag } \\
\text { e }\end{array}$ \\
\hline \multirow[t]{4}{*}{$\begin{array}{l}\text { Failure to increase buffer stock and lead time supply } \\
\text { chain performance }\end{array}$} & $\begin{array}{l}\text { Increased lead time } \\
\text { by } 0 \%-5 \%\end{array}$ & $0.00 \%$ \\
\hline & $\begin{array}{l}\text { Increased lead time } \\
\text { by } 6-10 \%\end{array}$ & $58.30 \%$ \\
\hline & $\begin{array}{l}\text { Increased lead time } \\
\text { by Over } 10 \%\end{array}$ & $41.70 \%$ \\
\hline & Total & $100.00 \%$ \\
\hline \multirow[t]{4}{*}{$\begin{array}{l}\text { Failure to increase buffer stock and quality of supply } \\
\text { chain performance }\end{array}$} & $\begin{array}{l}\text { Decreased quality } \\
\text { by } 0 \%-5 \%\end{array}$ & $0.00 \%$ \\
\hline & $\begin{array}{l}\text { Decreased quality } \\
\text { by } 6-10 \%\end{array}$ & $50.00 \%$ \\
\hline & $\begin{array}{l}\text { Decreased quality } \\
\text { by Over } 10 \%\end{array}$ & $50.00 \%$ \\
\hline & Total & $100.00 \%$ \\
\hline \multirow[t]{4}{*}{$\begin{array}{l}\text { Failure to increase buffer stock and cost of supply chain } \\
\text { performance }\end{array}$} & $\begin{array}{l}\text { Increased cost by } \\
0 \%-5 \%\end{array}$ & $0.00 \%$ \\
\hline & $\begin{array}{l}\text { Increased cost by } \\
6-10 \%\end{array}$ & $45.80 \%$ \\
\hline & $\begin{array}{l}\text { Increased cost by } \\
\text { Over } 10 \%\end{array}$ & $54.20 \%$ \\
\hline & Total & $100.00 \%$ \\
\hline
\end{tabular}

\subsubsection{Order Cycle Times}

The respondents were asked whether their company have a strategy that reduces order cycle times. Result in Figure 2 show that a majority of the respondents $(83.33 \%)$ indicated that their company have a strategy that reduces order cycle times. 
International Journal of Supply Chain and Logistics

ISSN

XXXX-XXXX

(Paper)

ISSN

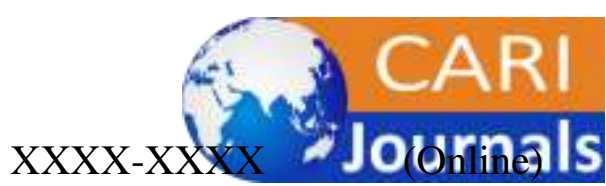

Vol.1, Issue No.2, pp82 - 100, 2017

www.carijournals.org

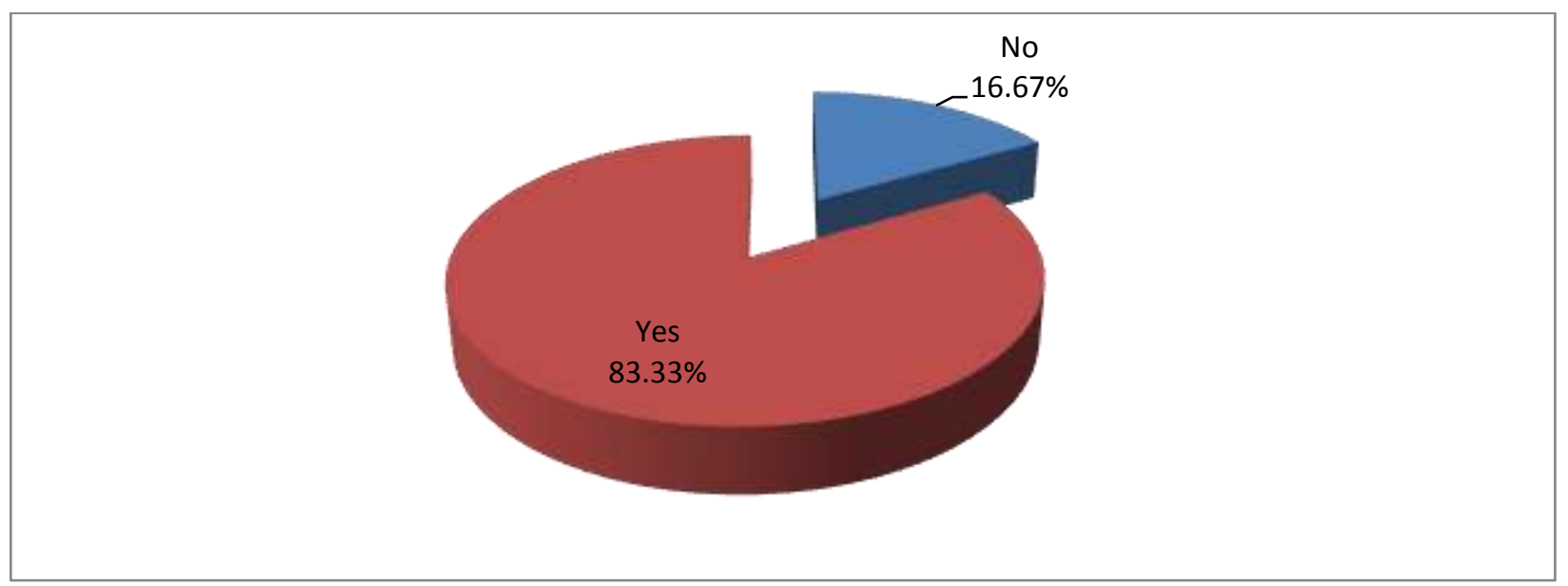

\section{Figure 2: Order Cycle Times}

Results in Table 3 show that majority of the respondents $(55.4 \%)$ indicated that having a strategy that reduces order cycle times has decreased lead time by more than $10 \%$ while $44.6 \%$ of the respondents indicated that having a strategy that reduces order cycle times has decreased lead time by a range of 6-10\%. Results in Table 3 also shows that majority of the respondents $(52.5 \%)$ indicated that having a strategy that reduces order cycle times has improved quality by more than $10 \%$ while $47.5 \%$ of the respondents indicated that having a strategy that reduces order cycle times has improved quality by a range of 6-10\%. Further, Results in Table 3 also shows that majority of the respondents $(53.5 \%)$ indicated that having a strategy that reduces order cycle times has reduced cost by more than $10 \%$ while $46.5 \%$ of the respondents indicated that having a strategy that reduces order cycle times has reduced cost by a range of 6-10\%. 
International Journal of Supply Chain and Logistics

ISSN

$\mathrm{XXXX}-\mathrm{XXXX}$

(Paper)

ISSN

xxxx-Xxxx Jooninals

Vol.1, Issue No.2, pp82 - 100, 2017

WwW.carijournals.org

Table 3: Order Cycle Times (YES)

\begin{tabular}{|c|c|c|}
\hline Statement & Indicator & Percentage \\
\hline \multirow[t]{4}{*}{$\begin{array}{l}\text { Order cycle times and lead time supply chain } \\
\text { performance }\end{array}$} & $\begin{array}{l}\text { Decreased lead time by } \\
0-5 \%\end{array}$ & $0.00 \%$ \\
\hline & $\begin{array}{l}\text { Decreased lead time by } \\
6-10 \%\end{array}$ & $44.60 \%$ \\
\hline & $\begin{array}{l}\text { Decreased lead time by } \\
\text { more than } 10 \%\end{array}$ & $55.40 \%$ \\
\hline & Total & $100.00 \%$ \\
\hline \multirow[t]{4}{*}{$\begin{array}{l}\text { Order cycle times and quality of supply chain } \\
\text { performance }\end{array}$} & $\begin{array}{l}\text { Improved quality by } 0- \\
5 \%\end{array}$ & $0.00 \%$ \\
\hline & $\begin{array}{l}\text { Improved quality by } 6- \\
10 \%\end{array}$ & $52.50 \%$ \\
\hline & $\begin{array}{l}\text { Improved quality by } \\
\text { more than } 10 \%\end{array}$ & $47.50 \%$ \\
\hline & Total & $100.00 \%$ \\
\hline \multirow{4}{*}{$\begin{array}{l}\text { Order cycle times and cost of supply chain } \\
\text { performance }\end{array}$} & Reduced cost by $0-5 \%$ & $0.00 \%$ \\
\hline & Reduced cost $6-10 \%$ & $46.50 \%$ \\
\hline & $\begin{array}{l}\text { Reduced cost by more } \\
\text { than } 10 \%\end{array}$ & $53.50 \%$ \\
\hline & Total & $100.00 \%$ \\
\hline
\end{tabular}

Results in Table 4 show that majority of the respondents $(58.3 \%)$ indicated that having a strategy that reduces order cycle times has increased lead time by a range of 6-10\% while $41.7 \%$ of the respondents indicated that having a strategy that reduces order cycle times has increased lead time by more than $10 \%$. Results in Table4also shows that $50 \%$ of the respondents indicated that having a strategy that reduces order cycle timeshas decreased quality by a range of $6-10 \%$ while $50 \%$ of the respondents indicated that having a strategy that reduces order cycle times has decreased quality by more than $10 \%$. Further, Results in Table 4 also shows that majority of the respondents $(54.2 \%)$ indicated that having a strategy that reduces order cycle times has increased cost by more than $10 \%$ while $45.8 \%$ of the respondents indicated that having a strategy that reduces order cycle timeshas increased cost by a range of 6-10\%.The results agrees with that of Rutherford, (2010) that increase in buffer stock in company help reduce risks along supply chain by reducing risk of stock, allows flexibility in case of unexpected delay in the supply chain.Company share supply chain costs with partners on cost involved dependent on type contract. 
International Journal of Supply Chain and Logistics

ISSN

XXXX-XXXX

(Paper)

ISSN

Vol.1, Issue No.2, pp82 - 100, 2017

www.carijournals.org

Table 4: Order Cycle Times (NO)

\begin{tabular}{|c|c|c|}
\hline Statement & Indicator & $\begin{array}{l}\text { Percentag } \\
\text { e }\end{array}$ \\
\hline \multirow[t]{4}{*}{$\begin{array}{l}\text { Lack of order times and lead time supply chain } \\
\text { performance }\end{array}$} & $\begin{array}{l}\text { Increased lead time } \\
\text { by } 0 \%-5 \%\end{array}$ & $0.00 \%$ \\
\hline & $\begin{array}{l}\text { Increased lead time } \\
\text { by } 6-10 \%\end{array}$ & $58.30 \%$ \\
\hline & $\begin{array}{l}\text { Increased lead time } \\
\text { by Over } 10 \%\end{array}$ & $41.70 \%$ \\
\hline & Total & $100.00 \%$ \\
\hline \multirow[t]{4}{*}{ Lack of order times and quality supply chain performance } & $\begin{array}{l}\text { Decreased quality } \\
\text { by } 0 \%-5 \%\end{array}$ & $0.00 \%$ \\
\hline & $\begin{array}{l}\text { Decreased quality } \\
\text { by } 6-10 \%\end{array}$ & $50.00 \%$ \\
\hline & $\begin{array}{l}\text { Decreased quality } \\
\text { by Over } 10 \%\end{array}$ & $50.00 \%$ \\
\hline & Total & $100.00 \%$ \\
\hline \multirow[t]{4}{*}{ Lack of order times and cost supply chain performance } & $\begin{array}{l}\text { Increased cost by } \\
0 \%-5 \%\end{array}$ & $0.00 \%$ \\
\hline & $\begin{array}{l}\text { Increased cost by } \\
6-10 \%\end{array}$ & $45.80 \%$ \\
\hline & $\begin{array}{l}\text { Increased cost by } \\
\text { Over } 10 \%\end{array}$ & $54.20 \%$ \\
\hline & Total & $100.00 \%$ \\
\hline
\end{tabular}

\subsubsection{Sharing Supply Chain Cost with Partners}

The respondents were asked whether their company share supply chain costs with partners. Result in Figure 3 show that a majority of the respondents $(80.83 \%)$ indicated that their company share supply chain costs with partners. 
International Journal of Supply Chain and Logistics

ISSN

XXXX-XXXX

(Paper)

ISSN

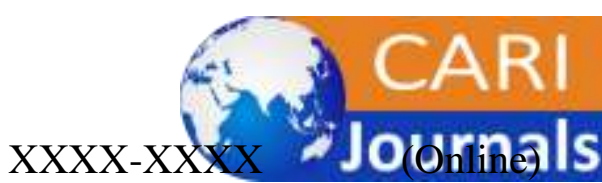

Vol.1, Issue No.2, pp82 - 100, 2017

www.carijournals.org

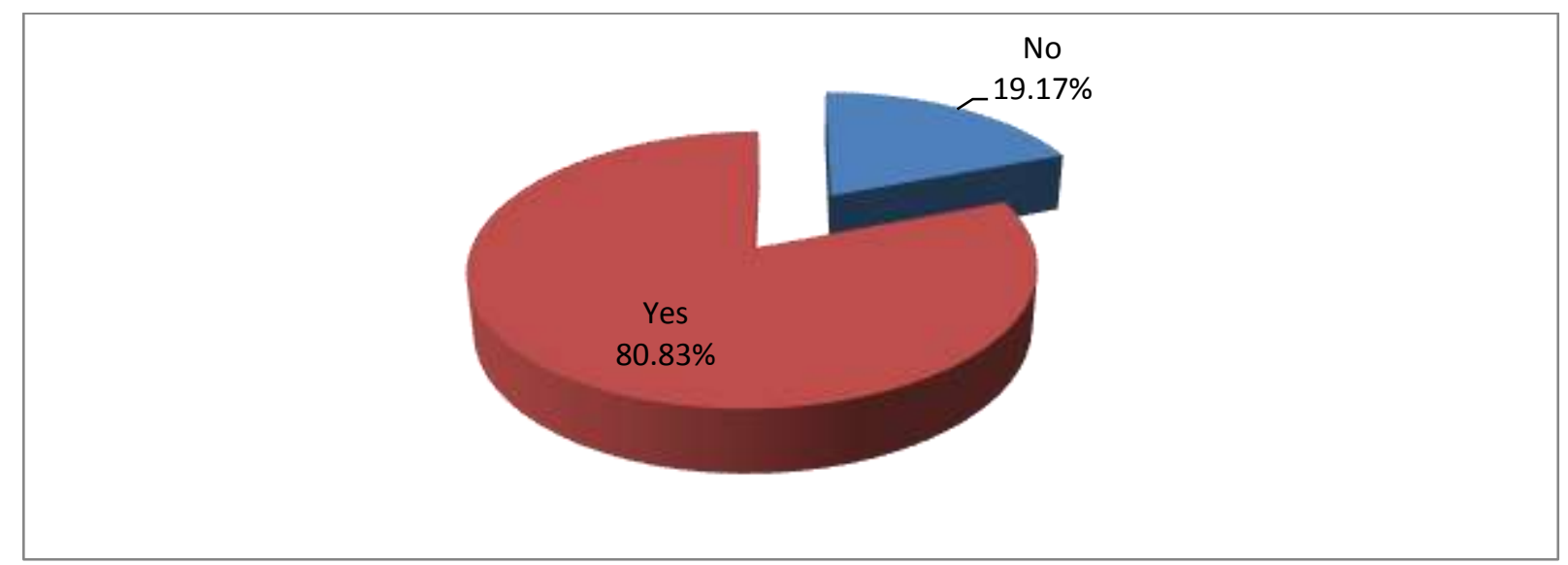

Figure 3: Sharing Supply Chain with Partners

Results in Table 5 show that $50 \%$ of the respondents indicated that sharing supply chain costs with partners has decreased lead time by a range of $6-10 \%$ while $50 \%$ of the respondents indicated that sharing supply chain costs with partnershas decreased lead time by more than $10 \%$. Results in table 5 also shows that majority of the respondents $(56.4 \%)$ indicated that sharing supply chain costs with partnershas improved quality by more than $10 \%$ while $43.6 \%$ of the respondents indicated that sharing supply chain costs with partnershas improved quality by a range of $6-10 \%$. Further, Results in Table 5 also shows that majority of the respondents $(55.3 \%)$ indicated that sharing supply chain costs with partnershas reduced cost by more than $10 \%$ while $44.7 \%$ of the respondents indicated that sharing supply chain costs with partners has reduced cost by a range of $6-10 \%$. 
International Journal of Supply Chain and Logistics

ISSN

$\mathrm{XXXX}-\mathrm{XXXX}$

(Paper)

ISSN

Vol.1, Issue No.2, pp82 - 100, 2017

www.carijournals.org

Table 5: Sharing Supply Chain with Partners (YES)

\begin{tabular}{|c|c|c|}
\hline Statement & Indicator & $\begin{array}{l}\text { Percentag } \\
\text { e }\end{array}$ \\
\hline \multirow[t]{4}{*}{$\begin{array}{l}\text { Sharing supply chain costs with partners and lead time } \\
\text { supply chain performance }\end{array}$} & $\begin{array}{l}\text { Decreased lead time } \\
\text { by } 0-5 \%\end{array}$ & $0.00 \%$ \\
\hline & $\begin{array}{l}\text { Decreased lead time } \\
\text { by } 6-10 \%\end{array}$ & $50.00 \%$ \\
\hline & $\begin{array}{l}\text { Decreased lead time } \\
\text { by more than } 10 \%\end{array}$ & $50.00 \%$ \\
\hline & Total & $100.00 \%$ \\
\hline \multirow[t]{4}{*}{$\begin{array}{l}\text { Sharing supply chain costs with partners and quality } \\
\text { supply chain performance }\end{array}$} & $\begin{array}{l}\text { Improved quality by } \\
0-5 \%\end{array}$ & $0.00 \%$ \\
\hline & $\begin{array}{l}\text { Improved quality by } \\
6-10 \%\end{array}$ & $43.60 \%$ \\
\hline & $\begin{array}{l}\text { Improved quality by } \\
\text { more than } 10 \%\end{array}$ & $56.40 \%$ \\
\hline & Total & $100.00 \%$ \\
\hline \multirow[t]{4}{*}{$\begin{array}{l}\text { Sharing supply chain costs with partners and cost } \\
\text { supply chain performance }\end{array}$} & $\begin{array}{l}\text { Reduced cost by } 0- \\
5 \%\end{array}$ & $0.00 \%$ \\
\hline & Reduced cost $6-10 \%$ & $44.70 \%$ \\
\hline & $\begin{array}{l}\text { Reduced cost by more } \\
\text { than } 10 \%\end{array}$ & $55.30 \%$ \\
\hline & Total & $100.00 \%$ \\
\hline
\end{tabular}

Results in Table 6 show that majority of the respondents (73.1\%) indicated that sharing supply chain costs with partners has increased lead time by more than $10 \%$ while $26.9 \%$ of the respondents indicated that sharing supply chain costs with partnershas increased lead time by a range of $6-10 \%$. Results in Table 6 also shows that majority of the respondents $(53.8 \%)$ indicated that sharing supply chain costs with partnershas decreased quality by a range of 6$10 \%$ while $46.2 \%$ of the respondents indicated that sharing supply chain costs with partnershas decreased quality by more than $10 \%$. Further, results in Table 6 also shows that majority of the respondents $(57.7 \%)$ indicated that sharing supply chain costs with partnershas increased cost by more than $10 \%$ while $42.3 \%$ of the respondents indicated that sharing supply chain costs with partnershas increased cost by a range of 6-10\%. 
International Journal of Supply Chain and Logistics

ISSN

XXXX-XXXX

(Paper)

ISSN

Vol.1, Issue No.2, pp82 - 100, 2017

Table 6: Sharing Supply Chain with Partners (NO)

\section{Statement}

Sharing supply chain costs with partners and lead time supply chain performance

\section{Indicator}

Increased lead

time by $0 \%-5 \% \quad 0.00 \%$

Increased lead

time by $6-10 \% \quad 26.90 \%$

Increased lead

time by Over $10 \% \quad 73.10 \%$

Total

$100.00 \%$
Sharing supply chain costs with partners and quality supply chain performance

Decreased quality

by $0 \%-5 \% \quad 0.00 \%$

Decreased quality

by $6-10 \% \quad 53.80 \%$

Decreased quality

by Over $10 \% \quad 46.20 \%$

Total $\quad 100.00 \%$

Sharing supply chain costs with partners and cost supply Increased cost by chain performance
$0 \%-5 \% \quad 0.00 \%$

Increased cost by

6- $10 \%$

$42.30 \%$

Increased cost by

Over $10 \%$

$57.70 \%$

Total 
International Journal of Supply Chain and Logistics

ISSN $\quad$ Xxxx-Xxxx $\quad$ (Paper) ISSN

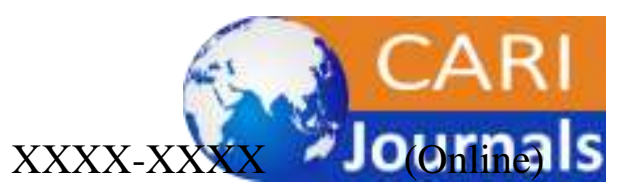

Vol.1, Issue No.2, pp82 - 100, 2017

www.carijournals.org

\subsubsection{Relationship between Hedging against Risk Management Strategy and Better Lead Time}

Results in Table 7 show the results of the odd ratio regression with regard to lead time. The result reveals that increasing buffer stock at various levels in the supply chainhad a positive and significant relationship with lead time. The odds of observing better lead time were 3.249 times higher for those that had the practise of increasing buffer stock at various levels in the supply chain. This implies that the practice of increasing buffer stock at various levels in the supply chainresult to better lead time. These results reveal that sharing supply chain costs with partners had a positive and significant relationship with lead time. The odds of observing better lead time were 5.123 times higher for those that had the practise of sharing supply chain costs with partners. This implies that the practice of sharing supply chain costs with partners result to better lead time.

Table 7: Odd Ratio Regression for Hedging against Risk (Lead Time)

\begin{tabular}{lrrrrrc}
\hline \multicolumn{1}{c}{ Variable } & B & S.E. & Wald & df & Sig. & $\operatorname{Exp(B)}$ \\
\hline Increase buffer stock at various levels in & 1.178 & 0.602 & 3.836 & 1 & 0.050 & 3.249 \\
the supply chain & & & & & & \\
Reduce order cycle times & 1.313 & 0.697 & 3.544 & 1 & 0.060 & 3.716 \\
Share supply chain costs with partners & 1.634 & 0.603 & 7.345 & 1 & 0.007 & 5.123 \\
Constant & -2.27 & 0.695 & 10.65 & 1 & 0.001 & 0.103 \\
& & & 8 & & & \\
\hline
\end{tabular}

\subsubsection{Relationship between Hedging against Risk Management Strategy and Better Quality}

Results in Table 8 show the results of the odd ratio regression with regard to quality. The result reveals that increasing buffer stock at various levels in the supply chainhad a positive and significant relationship with quality. The odds of observing better quality were 9.965 times higher for those that had the practise of increasing buffer stock at various levels in the supply chain. This implies that the practice of increasing buffer stock at various levels in the supply chain result to better quality. The result reveals that sharing supply chain costs with partners had a positive and significant relationship with quality. The odds of observing better quality were 4.376 times higher for those that had the practise of sharing supply chain costs with partners. This implies that the practice of sharing supply chain costs with partners result to better quality. 
International Journal of Supply Chain and Logistics

ISSN

XXXX-XXXX

(Paper)

ISSN

Vol.1, Issue No.2, pp82 - 100, 2017

www.carijournals.org

Table 8: Odd Ratio Regression for Hedging against Risk (Quality)

\begin{tabular}{lllllll}
\hline \multicolumn{1}{c}{ Variable } & B & S.E. & Wald & $\begin{array}{l}\text { d } \\
\text { f }\end{array}$ & Sig. & Exp(B) \\
& & & & & \\
\hline Increase buffer stock at various levels & 2.299 & 0.619 & 13.81 & 1 & 0.000 & 9.965 \\
in the supply chain & & & 2 & & & \\
Reduce order cycle times & 1.093 & 0.73 & 2.24 & 1 & 0.135 & 2.984 \\
Share supply chain costs with partners & 1.476 & 0.652 & 5.119 & 1 & 0.024 & 4.376 \\
Constant & -2.747 & 0.757 & 13.15 & 1 & 0.000 & 0.064 \\
& & & 7 & & & \\
\hline
\end{tabular}

\subsubsection{Relationship between Hedging against RiskManagement Strategy and Better Cost}

Results in Table 9 show the results of the odd ratio regression with regard to cost. The result reveals that increasing buffer stock at various levels in the supply chain, reducing order cycle times and sharing supply chain costs with partners had a positive but insignificant relationship with cost. This implies that increasing buffer stock at various levels in the supply chain, reducing order cycle times and sharing supply chain costs with partners do not influence cost.

Table 9: Odd Ratio Regression for Hedging against Risk (Cost)

\begin{tabular}{|c|c|c|c|c|c|c|}
\hline Variable & B & S.E. & $\begin{array}{c}\text { Wal } \\
\text { d }\end{array}$ & $\begin{array}{l}\text { d } \\
\mathbf{f}\end{array}$ & Sig. & $\operatorname{Exp}(B)$ \\
\hline $\begin{array}{l}\text { Increase buffer stock at various levels in } \\
\text { the supply chain }\end{array}$ & 0.739 & 0.558 & 1.758 & 1 & 0.185 & 2.094 \\
\hline Reduce order cycle times & 0.583 & 0.657 & 0.787 & 1 & 0.375 & 1.792 \\
\hline Share supply chain costs with partners & 0.85 & 0.568 & 2.237 & 1 & 0.135 & 2.339 \\
\hline Constant & -0.766 & 0.545 & 1.973 & 1 & 0.160 & 0.465 \\
\hline
\end{tabular}

These findings agrees with that of Jüttner, (2005) that introducing controls in supply chains to reduce the consequences of the risk event, through hedging minimize the disruptions that may be as a result of supply chain vulnerability.

\subsection{Hypothesis Testing}

The hypothesis was tested by running an ordinary least square regression model. The acceptance/rejection criteria was that, if the $\mathrm{p}$ value is greater than 0.05 , the Ho is not rejected 
International Journal of Supply Chain and Logistics

ISSN

XXXX-XXXX

(Paper)

ISSN

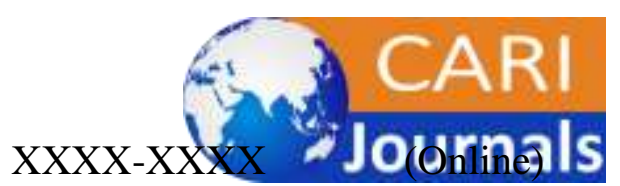

Vol.1, Issue No.2, pp82 - 100, 2017

www.carijournals.org

but if it's less than 0.05, the Ho fails to be accepted. The null hypothesis for this objective was: Hedging risk management strategy has no significant effect on supply chain performance among manufacturing companies in Kenya. The alternative hypothesis for this objective was: Hedging risk management strategy has significant effect on supply chain performance among manufacturing companies in Kenya.

The null hypothesis was not rejected hence hedging risk management strategy has no significant effect on supply chain performance among manufacturing companies in Kenya.

Table 10: Hedging risk management strategy model ANOVA

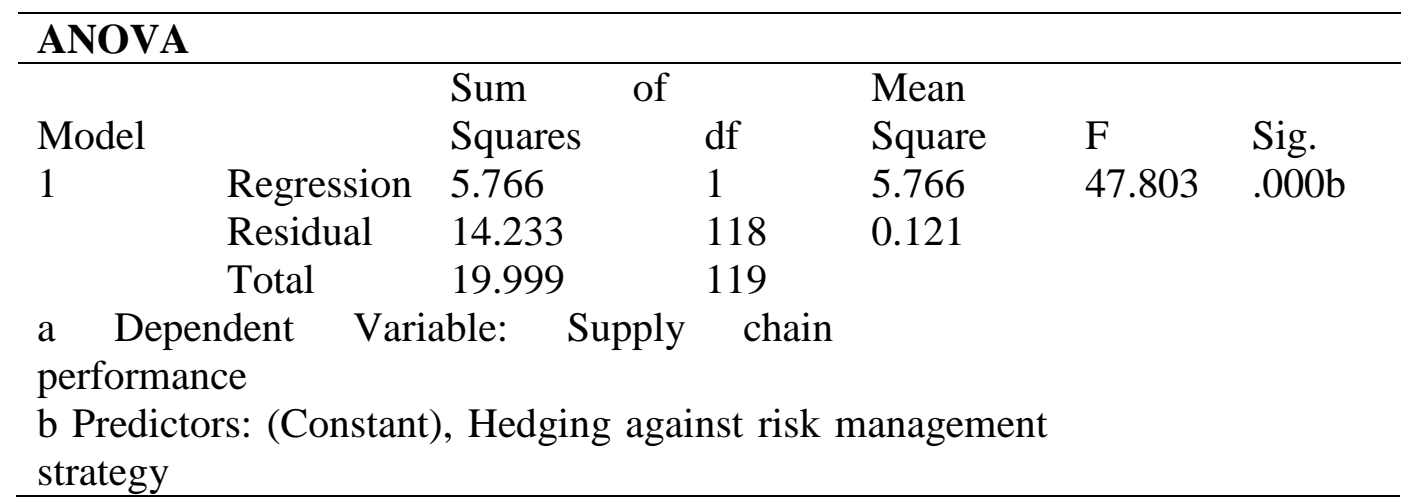

Table 11: Hedging risk management strategy model summary

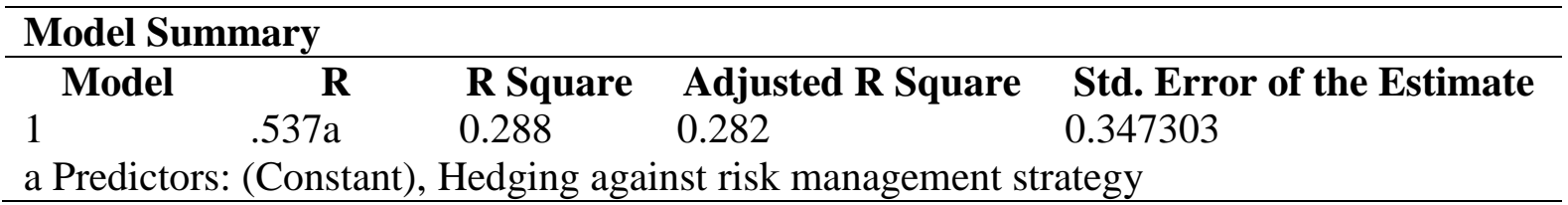

Table 12: Hedging risk management strategy model coefficients

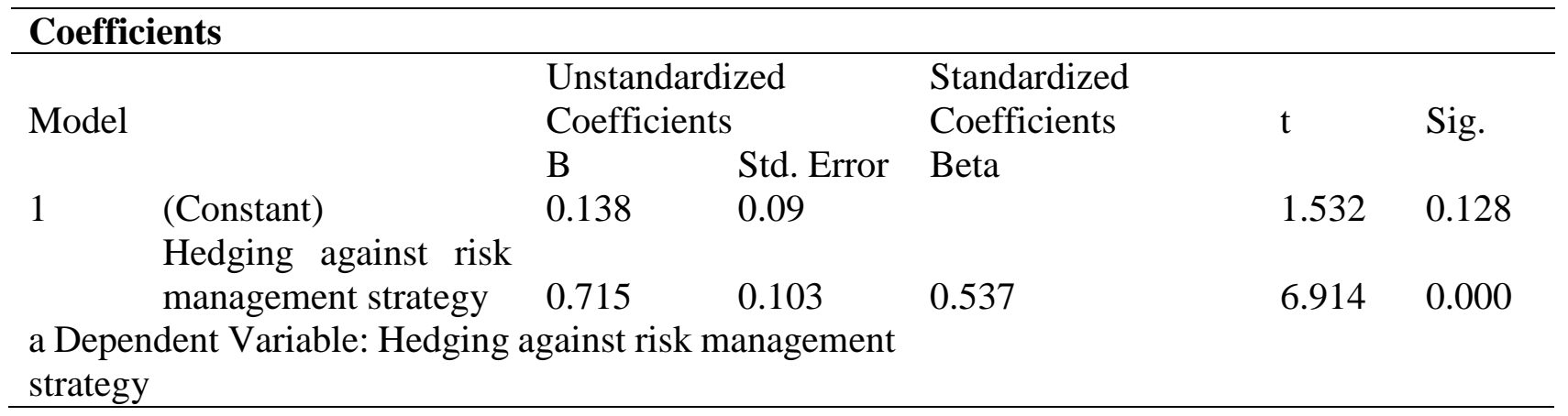


International Journal of Supply Chain and Logistics

ISSN $\quad$ Xxxx-xxxx $\quad$ (Paper) ISSN

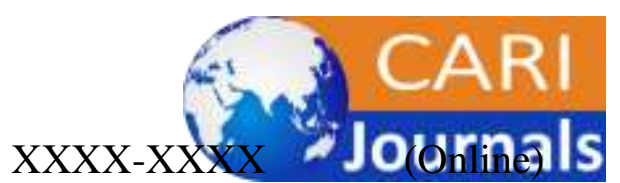

Vol.1, Issue No.2, pp82 - 100, 2017

www.carijournals.org

The F statistic for the model was significant at 5\% level of significance implying that the model fit well. The results of the regression model reveal that hedging against risk management strategy explains $28.8 \%$ of the changes in supply chain performance.

The relationship between hedging against risk management strategy and supply chain performance was significant at 5\% level of significance. The p-value was 0.000 which indicated that the null hypothesis was not accepted at 5\% level of significance hence hedging against risk management strategy has significant effect on supply chain performance among manufacturing companies in Kenya.

\subsection{SUMMARY OF FINDINGS, CONCLUSIONS AND RECOMMENDATIONS}

\subsection{Summary of Finding}

The fourth objective of the study was to determine the effect of hedging risk management strategy on supply chain performance among manufacturing companies in Kenya. Result showed that most of the companies that increased buffer stock at various levels in the supply chain increasing buffer stock at various levels in the supply chainresulted to decreased lead time, improved quality and reduced cost. Results also showed that most of the companies 'conductedreduce order cycle times. Conducting reduce order cycle times resulted to decreased lead time, improved quality and reduced cost. Further, the results revealed that most of the companies shared supply chain costs with partners. Sharing supply chain costs with partnersresulted to decreased lead time, improved quality and reduced cost.

The bivariate regression results indicated that the odds of improved lead time were higher for those companies that increased buffer stock at various levels in the supply chain and shared supply chain costs with partners. The results further indicated that the odds of improved quality were higher for those companies that increased buffer stock at various levels in the supply chain and shared supply chain costs with partners. The multivariate regression results indicated that the odds of observing improved cost were higher for those companies that had a hedging against risk management strategy in place. The results indicated that hedging against risk management strategy did not influence the odds of better supply chain performance in any way.

\subsection{Conclusion}

Based on the study findings the study concluded that most of the companies had hedging against risk management strategy in place. This conclusion was arrived at from the observation that most companies increased buffer stock at various levels in the supply chain, reduced order cycle times and shared supply chain costs with partners. The study concluded that the odds of observing better lead time and improved quality were higher for increasing buffer stock at various levels in the supply chain and sharing supply chain costs with partners. The study concludes that having hedging against risk management strategy in place does not determine the performance of supply chain in manufacturing companies.

\subsection{Recommendations of the Study}

The study also recommended that manufacturing companies should put in place hedging against risk management strategies. In particular, the companies should consider increasing 
International Journal of Supply Chain and Logistics

ISSN

XXXX-XXXX

(Paper)

ISSN

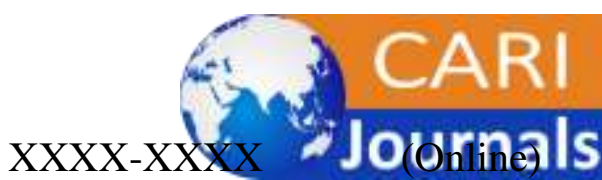

Vol.1, Issue No.2, pp82 - 100, 2017

www.carijournals.org

buffer stock at various levels in the supply chain and sharing supply chain costs with partners. This would assist to boost supply chain performance.

\subsection{Suggested Areas for Further Study}

Further studies can be done on the effect of risk management strategies that influence the supply chain performance of service delivery companies. In addition further studies are recommended in the area of competitive strategies and strategic responses adopted by manufacturing companies in order to improve supply chain performance.

In addition, further studies may investigate the influence of demographic factors on the risk management strategies of manufacturing companies. For instance, are manufacturing companies with a high male gender composition more likely to put in place effective risk identification, risk analysis and evaluation, risk monitoring and control and hedging against risk management strategies? What is the potential effect of the type of company on risk management strategies? What is the potential effect of the age of company on risk management strategies? What is the impact of gender composition, experience, age of manufacturing companies' employees on supply chain performance? Studies may be carried out to find answers to these questions.

\section{REFERENCES}

Allayannis, G., G. W. Brown, \& L. F. Klapper, 2001, Exchange Rate Risk Management: Evidence from East Asia. University of Virginia Working Paper, Nov/19/2000, Darden School of Business, USA

Allen, Norman, \& Robert L. 2004.Categorization of Supply Chain Risk and Risk Management, in Supply Chain Risk.Edited by C. Brindley. London: Ashgate Publishers.

Ambira, C.M. \&Kemoni, H., (2011), 'Records management and risk management at Kenya Commercial Bank Limited, Nairobi', SA Journalof Information Management 13(1), 475-488

Awino, Z.B \&Gituro, W. (2011), An Empirical Investigation of Supply Chain Management

Best Practices in Large Private Manufacturing Firms in Kenya.Prime Journal of Business Administration and Management (BAM).1(12):26-31.

Beth, E, Bertok, J \&Vergez, C (2007), Integrity in Public Procurement: Good Practice From A To Z, Paris, OECD Publishing

Blos, M., Quaddus, M., Wee, H. \& Watanabe, K. (2009), Supply chain risk management: a case study of automotive and electronic industries in Brazil, Supply Chain Management: An International Journal, 14(4), 247-252

Chan, H., Wang, W., Luong, L.\& Chan, F. (2009), "Flexibility and adaptability in supply chains: a lesson learned from practitioners", Supply Chain Management: An International Journal, 14(6), 407-410

Chen, H.X., Amodeo, L., Chu, F. \&Labadi, K. (2005), "Modelling the performance evaluation of supply chains using batch deterministic and stochastic Petri nets", IEEE Transactions on Automated Science and Engineering, 2(2), 78-85Performance, 3rd ed., Supply Chain Management Institute, Sarasota, FL

Leo O. O., (2009) 'Kenya is likely to lose billions in erratic tendering system' African Press International 
International Journal of Supply Chain and Logistics

ISSN

XXXX-XXXX

(Paper)

ISSN

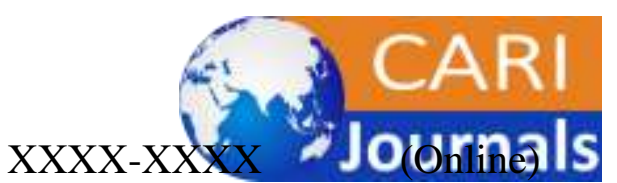

Vol.1, Issue No.2, pp82 - 100, 2017

www.carijournals.org

Li, G., Yan, H., Wang, S.Y. \& Xia, Y.S. (2005), Comparative analysis on value of information sharing in supply chains, Supply Chain Management: An International Journal, 10(1), $34-46$

Lowe, A. \& Jones, A. (2004), Emergent strategy and the measurement of performance: the formulation of performance indicators at the micro level, Organization Studies, 25(8), 1313-1337

Lysons, K., Farrington, B. (2006), Purchasing and Supply Chain Management, 7th ed., FT, Prentice-Hall, Pearson Education Ltd, Upper Saddle River, NJ, .

Mugenda\&Mugenda (2003), Research methods: qualitative and quantitative approaches. N.J.: Lawrence Erlbaum Associates

Natarajarathinam, M., Capar, I. \& Narayanan, A. (2009), Managing supply chains in times of crisis: a review of literature and insights, International Journal of Physical Distribution \&Logistics Management, 39(7), 535-573

Neely, A., Mills, J., Platts, K., Richards, H., Gregory, M., Bourne, M. \&Kennerley, M. (2000), "Performance measurement system design: developing and testing a process-based approach", International Journal of Operations \& Production Management, 20(4), 640-661.

OrodhoJ.A,\&Kombo K (2004), Techniques of writing research proposal and reports in education and social sciences, Nairobi, Masola Publisher

Patrick A. (2009), Procurement challenges in public sector organizations. Journal of management, 11(2), 157-166

Peck, H. (2005), Drivers of supply chain vulnerability: an integrated framework, International Journal of Physical Distribution \& Logistics Management, 35(4), 210-232

Richard H., John F., (2012) Sustainable SME practice: A reflection on supply- chain environmental management intervention, Management of Environmental Quality: An International Journal, 23(6), 673-685

Richard L. Draft, Martyn K., \& Natalia V., (2008); Management: International Edition, $8^{\text {th }}$ Edn, Boston USA, Nelson education ltd (Cengage Learning)

Ritchie, B. \&Brindley, C. (2007), Supply chain risk management and performance, A guiding framework for future development, International Journal of Operations \& Production Management, 27(3), 303-322 